\title{
MULTICULTURAL VALUES IN INDONESIAN NOVELS OF THE 2000s
}

\author{
Suminto A. Sayuti and Wiyatmi \\ School of Languages and Arts, Yogyakarta State University \\ email: suminto_sayuti@uny.ac.id
}

\begin{abstract}
This study was aimed at describing multicultural values, ways of expressing multicultural values, and the dynamics of multicultural values in Indonesian novels of the 2000s. The study purposively selected a sample of six novels that intensely carried the theme of multiculturalism. These were Laskar Pelangi, Larung, Jendela-jendela, Ayat-ayat Cinta, Jepun Negerinya Hiroko, and Partikel. The study used the descriptive qualitative method. The study obtained the following findings. First, there were four main multicultural values: (a) apreciasion of cultural pluralism, (b) valuing of the principles of humanism and fundamental human rights (FHR), (c) responsibility of the international society, (d) responsibility of the planet earth. Second, multicultural values are expressed through narrative elements and become an integral part of the entire story. Third, multicultural values move in the dynamics of locality to nationality and nationality to globality. Indonesian novels of the 2000s express Indonesian people in the contexts of world nation and citizens who are multicultural, having appreciative minds towards cultural pluralism, upholding humanism and FHR, taking responsibilities of sustaining the entirety of the world and planet earth.
\end{abstract}

Keywords: multicultural, Indonesian novel, nasionality, globality, plurality

\section{NILAI MULTIKULTURAL DALAM NOVEL-NOVEL INDONESIA 2000-AN}

\begin{abstract}
Abstrak
Penelitian ini bertujuan untuk mendeskripsikan nilai-nilai multikultural, cara pengekspresian nilai multikultural, dan dinamika nilai multikultural dalam novel-novel Indonesia 2000-an. Penelitian ini secara purposif memilih enam judul novel sebagai sampel yang secara intens mengusung tema multikulturalisme. Keenam judul novel tersebut adalah Laskar Pelangi, Larung, Jendela-jendela, Ayat-ayat Cinta, Jepun Negerinya Hiroko, dan Partikel. Penelitian ini menggunakan metode deskriptif kualitatif. Hasil penelitian sebagai berikut. Pertama, terdapat empat nilai multikultural pokok: (a) apresiasi terhadap pluralisme budaya, (b) penghargaan terhadap hakikat kemanusiaan dan HAM, (c) tanggung jawab masyarakat dunia, dan (d) tanggung jawab planet bumi. Kedua, nilai-nilai multikultural tersebut diekspresikan melalui unsur-unsur naratif dan menjadi bagian integral dalam keseluruhan cerita. Ketiga, nilai-nilai multikultural bergerak dalam dinamika lokalitas menuju nasionalitas dan nasionalistas menuju globalitas. Novel-novel Indonesia 2000-an mencoba mengekspresikan manusia Indonesia dalam konteks bangsa dan warga dunia yang multikultural, yang memiliki jiwa apresiatif terhadap pluralisme budaya, menjunjung tinggi harkat kemanusiaan dan HAM, dan ikut bertanggung jawab menjaga kedamaian dan keutuhan dunia dan planet bumi.
\end{abstract}

Kata kunci: multikultural, novel Indonesia, nasionalitas, globalitas, pluralitas 


\section{INTRODUCTION}

Indonesia is an archipelago built of diverse ethnics and cultures. The nation slogan, diversity in unity, different but remaining one, shows the existence of the nation and culture, which is: varied but one. One consequence of this condition brings up the problem of multiculturalism, a social factuality that must be faced (Tilaar, 2009:202).

As a multicultural country, in the movement for independence since the national arising era, the Indonesian nation has made efforts to build a society and nation that are founded on cultural equalities. The Youth Oath is one of the factual evidences. In the same way, the drafting of the Preamble of the 1945 Constitution shows the spirit of multiculturalism of the leaders of the Indonesian nation at that time (Tilaar, 2009:205).

In a wider context, Indonesia is presently a part of a big village (global villlage), as stated by the communication expert McLuhan (Tilaar, 2009:211). The multicultural identity of the Indonesian nation which basically is trans-local moves forward to globality. This way, the Indonesian nation identity cannot be detached from the entries of a varied array of values from the "outside" by way of various modern media and international interactions. This has given a unique colour and texture to the cultural aspects of the nation life. It is true, however, that penetration of new values often comes to contradiction with ones that have long been internalized and believed. Inclination towards materialism and hedonism in the society that tends to be more consumerist, and a long list of other such phenomena, is an inevitable path facing the nation, including how national values begin to fade (not to say "to be forgotten").

In relation to the background condition above, a need is felt for the formulation of multicultural values that must be understood by the present generation in order that they develop as quality members in the interethnic and international interactions. These multicultural values can be found in the works of culture, including literary works. By reading literary works, readers, including young people, will be able to learn and internalize multicultural values in the contexts of translocality dan globality. It is by that reason that research is needed to analyze multicultural values that can subsequently be used as bases to formulate basic concepts of multicultural education in the teaching of literature in schools and universities.

Based on this background of the problem, this study is aimed at uncovering and eliciting multicultural values that are contained in the Indonesian novels of the 2000s, they ways they are expressed, and their dynamics in the dialogues of the locality, translocality, and globality to be subsequently implemented in the teaching of literature in schools and universities.

The urgency of this study is indicated by the needs to re-identify multicultural values that have characterized the Indonesian people as documented in cultural works, especially Indonesian novels of the 2000s. The assumption is that these novels are written based on the sociocultural phenomena within the society, including the diverse cultures that live in Indonesia. By studying the multicultural values that are contained in the Indonesian novels, it can be rediscovered how the Indonesian society - as pictured in the Indonesian literary works - has lived in the multicultural conditions. Results of the study can then be used as a basis for developing instructional modules for the teaching of literature in high schools and universities. Through the learning of literature with multicultural perspectives, the younger generation who will be part of the nation leaders in the future is expected to have understanding of 
multicultural values so that they will have appreciation toward pluralism, strongly uphold humanism and FHR, and take responsibility of the planet earth and world community.

The concept of multicultural values refers appreciation of the existence of cultural diversity. Multicultural values cannot be separated from the idea of multiculturalism. Multiculturalism simply means the differences in cultures. In accordance with Tilaar (2009:82), multiculturalism is a trend or belief that acknowledges the existence of cultural differences. Multiculturalism is an important belief to be developed in Indonesia as a country consisting of varied islands, ethnics, languages, and cultures. With multiculturalism, one will be prevented from thinking that a certain one nation, language, or culture is more superior to any other nation, language, or culture.

Multiculturalism, according to Parekh (2008:15), is not merely concerned with differences and identities that are related to beliefs and practices of a certain community group to understand their selves and their world and to organize their individual or collective lives. Multiculturalism, more than that, is concerned with diversities; differences that are culturally attached, so that it is more known as cultural diversities. Parekh (2008:16) distinguishes cultural diversities in the modern society into several forms three of which are subcultural diversity, perspective diversity, and communal diversity. Sub-cultural diversity is attached to a culture owned together by a group that is expected to be wide open, varied, and not conflicting among each other. The group members have a broad common culture; some of them have a different belief and practices concerning a certain area of their life or they pursue their own way of life that is relatively quite different. According to Parekh, these are, among others, wealthy transnational executives, artists, and those who have unconventional ways of life or family structures such as gays, lesbians, bi-sex marriages, unmarried couples.

Perspective diversity refers to a certain society group whose members are critical toward certain principles and values of the central cultures and attempt to redefine them along their group line. They challenge the basic understanding of the existing culture reflecting the intellectual perspectives on how the dominant culture should be redefined (Parekh, 2008:1617). The feminists attack the patriarchic biases, religious groups attack secular orientations, conservationists attack anthropocentrism and technocratism are examples of perspective diversity according to Parekh. Communal diversity refers to communities that are self-aware, more or less organized, and live by life beliefs and practices that are different. These are new immigrants, long-settled groups like the Jews and the Gypsies, other cultural communities residing in certain territories, and others (Parekh, 2008:16-17).

The root of the word multiculturalism is culture. In this relation, culture is seen from its functional perspective; that is, how culture becomes a life guide for people's life. Multiculturalism is a discourse in the field of culture within a wide sense such as identities of a nation-state and power. Development of a nation-state identify is important in that it will give a sense of identity to the members of this nation group. And then, a nation-state will be able to defend itself if it has power; power to sustain life, develop in the community group, and tie the group in a life unit (Tilaar, 2009: 203).

Multicultural values cover (1) appreciation of cultural pluralism, (2) natures of man and FHR, (3) responsibility of planet earth, (4) responsibility of world community (Bennett, via Tilaar, 2009; 209). Further, the four core values are 
related to six multicultural objectives of (1) developing varied historical perspectives, (2) strengthening cultural awareness, (3) elevating intercultural competencies, (4) curbing racism, sexsism, and other prejudices, (5) developing awareness of planet earth ownership, and (6) improving social action competencies (Bennett, via Tilaar, 2009;209). In order to build a democratic society, these multicultural values need to be socialized and taught to the members of the society, especially the young generation, through education programs.

In practice, Tilaar (2009: 206) reminds, two things must be taken into account in multicultural education: that it is a process and it is multi-facet. As a process, a multicultural education program undergoes formulation, reflection, and action in the field in line with the development of the fundamental concepts of education and human rights. Being multi-facet, multicultural education requires inter-disciplinary efforts from the experts and practitioners of education to refine and sharpen the concepts of multicultural education for the Indonesian society.

\section{METHOD}

This study used the descriptive, qualitative, and interpretive design. It was aimed at describing and understanding the multicultural values that are contained in the Indonesian novels of the 2000s: how these values are expressed in the novels and what are the dynamics of the values in the locality, translocality, and globality dialogues.

Sources of the data were Indonesian novels of the 2000s selected purposively; that is, novels that carried the setting of various ethnics and cultures in the local, translocal, and global contexts. The novels that satisfied this requirement were (1) Larung (Ayu Utami, 2001), (2) Laskar Pelangi (Andrea Hirata, 2005), (3) Jendela- jendela (Fira Basuki, 2001), (4) Ayat-ayat Cinta (Habiburrahman El Shirazy, 2006), (5) Jepun Negerinya Hiroko (Nh. Dini, 2001), and (6) Supernova Partikel (Dee, 2012). These six novels were taken to represent multiculturalism in the context of locality, that is the diversity of interethnic cultures in Indonesia and globality, that is the diversity of global cultures around the world in relation to Indonesian cultures. From these sources, data were elicited from the story facts that were related to the research questions. In addition, data were also collected on information concerning various ethnic and culture identities in the contexts of locality, translocality, and globality. These data were written on data cards and classified according to the information related to the research questions.

Data coming from the novels were analyzed using the qualitative interpretive text analysis under the literary sociology approach. Multicultural values expressed in the novels were understood in their relation with the social contexts of the Indonesian people in the local, translocal, and global dynamics.

\section{Findings and Discussion}

Data analyses of the study produce results that are presented as follows. (Table 1)

In the Indonesian novels of the 2000s, the multicultural values that are studied are integral parts of the stories expressed within narrative elements as follows. (Table 2)

The multicultural values from the six novels that are analyzed move dynamically from the locality to nationality and globality. This can be seen in the following table. (Table 3)

Indonesian People in the Arena of Multicultural Communities

In the six novels that are studied, four groups of core multicultural values 
Table 1. Multicultural Values in the Indonesian Novels of the 2000s

\begin{tabular}{|c|c|c|c|}
\hline No. & Novel & Multicultural contexts & Multicultural values \\
\hline 1. & Laskar Pelangi & $\begin{array}{l}\text { Interethnic: encounter } \\
\text { between Malay culture } \\
\text { (Belitong) and Chinese }\end{array}$ & $\begin{array}{l}\text { (1) Appreciation toward cultural } \\
\text { pluralism } \\
\text { (2) Valuation toward humanism and FHR }\end{array}$ \\
\hline 2. & Larung & $\begin{array}{l}\text { Interethnic and nation: } \\
\text { encounter among the } \\
\text { cultures of Java-Bali-North } \\
\text { Sumatra (Batak)-Manado- } \\
\text { America }\end{array}$ & $\begin{array}{l}\text { (1) Appreciation toward cultural } \\
\text { pluralism } \\
\text { (2) Valuation toward humanism and FHR }\end{array}$ \\
\hline 3. & $\begin{array}{l}\text { Jendela- } \\
\text { jendela }\end{array}$ & $\begin{array}{l}\text { Interethnic: Indonesia- } \\
\text { Tibet-America-Singapore }\end{array}$ & $\begin{array}{l}\text { (1) Appreciation toward cultural } \\
\text { pluralism }\end{array}$ \\
\hline 4. & $\begin{array}{l}\text { Ayat-ayat } \\
\text { Cinta }\end{array}$ & $\begin{array}{l}\text { Interethnic: Indonesia- } \\
\text { Egypt-Turkey }\end{array}$ & $\begin{array}{l}\text { (1) Appreciation toward cultural } \\
\text { pluralism } \\
\text { (2) Valuation toward humanism and FHR }\end{array}$ \\
\hline 5. & $\begin{array}{l}\text { Jepun } \\
\text { Negerinya } \\
\text { Hiroko }\end{array}$ & $\begin{array}{l}\text { Interethnic: Indonesia- } \\
\text { France-Japan }\end{array}$ & $\begin{array}{l}\text { (1) Appreciation toward cultural } \\
\text { pluralism }\end{array}$ \\
\hline 6. & Partikel & $\begin{array}{l}\text { Interethnic: Indonesia- } \\
\text { England-America }\end{array}$ & $\begin{array}{l}\text { (1) Appreciation toward cultural } \\
\text { pluralism } \\
\text { (2) Valuation toward humanism and FHR } \\
\text { (3) Responsibility of world community } \\
\text { (4) Responsibility of planet earth }\end{array}$ \\
\hline
\end{tabular}

Table 2. Expressions of Multicultural Values in Indonesian Novels of the 2000s

\begin{tabular}{|c|c|c|c|c|}
\hline No. & $\begin{array}{c}\text { Multicultural } \\
\text { values }\end{array}$ & $\begin{array}{l}\text { Fiction } \\
\text { elements }\end{array}$ & & Multicultural issuesin the novel \\
\hline \multirow[t]{4}{*}{1.} & $\begin{array}{l}\text { Appreciation toward } \\
\text { cultural pluralism }\end{array}$ & $\begin{array}{l}\text { Character, } \\
\text { setting, } \\
\text { issues being } \\
\text { raised }\end{array}$ & (a) & $\begin{array}{l}\text { Laskar Pelangi: indigenous people of } \\
\text { Belitong live side by side peacefully } \\
\text { with the Chinese who form a third of } \\
\text { the total population of (LP, 35); one of } \\
\text { the pupils of Muhammadiyah } \\
\text { Elementary School Gentong is from the } \\
\text { Chinese ethnic (A Kiong); Ikal falls in } \\
\text { love with A Ling. }\end{array}$ \\
\hline & & & (b) & $\begin{array}{l}\text { Larung: friendship of characters from } \\
\text { various ethnics; Java (Shakuntala, } \\
\text { Saman, Laila), Batak (Sihar Situmorang), } \\
\text { Menado (Yasmin Moningka), Bali (Cok } \\
\text { and Larung) }\end{array}$ \\
\hline & & & (c) & $\begin{array}{l}\text { Larung: Indonesians work and study in } \\
\text { the US (Sakhuntala studies and dances } \\
\text { in the US) }\end{array}$ \\
\hline & & & (d) & $\begin{array}{l}\text { Ayat-ayat Cinta: An Indonesian studies } \\
\text { at the University of Al Azhar, Egypt; } \\
\text { makes friends with people from other }\end{array}$ \\
\hline
\end{tabular}


2. Valuation toward humanism and FHR

3. Responsibility to world community

4. Responsibility to planet earth
Character, setting, issues being raised countries; marries a Turkey girl of the blood of Palestine, German, and Turkish.

(e) Jepun Negerinya Hiroko: an Indonesian marries a foreigner (French) and lives in Japan.

(f) Partikel: interethnic marriage in an interethnic team; Zarah's grandfather is Arab-Sundanese. Zarah (Indonesia) is a friend of and works in a team with Mrs Inga (Canada) and Paul dan Gary (London).

(a) Laskar Pelangi: ethnic and religious differences do not bar people from getting education and falling in love with each other; A Kiong from the Chinese ethnic is sent to Muhammadiyah Elementary School at Gantong.

(b) Larung: Saman works in an FHR NGO in the US

(c) Ayat-ayat Cinta: Fahri criticizes the conducts of two Egyptians (Ashraf and a youth in a box-styled shirt) who speak and behave rudely to American tourists and a veiled woman who defend the American tourists in a metro.

(d) Partikel: a group of people from various countries and ethnics (Indonesia, Canada, England) meet in a joint movement to save orangutans in Tanjung Puting, Kalimantan and wildlife photography as part of activities to save the environment and humanity aids

Character, Partikel: Humanity aids for natural setting, disasters, health research (such as AIDS) issues being become the responsibility of all people in raised the world.

Character, Partikel: the saving of orangutans in setting, issues being raised Tanjung Puting, Kalimantan; preserving life environments, introducing the earth and all its contents, especially rare animals from various parts of the world through wildlife photography. 
Tabel 3. The Dynamics of the Multicultural Values in Indonesian Novels of the 2000s

\begin{tabular}{|c|c|c|c|}
\hline No. & $\begin{array}{l}\text { Dynamics of the } \\
\text { multicultural } \\
\text { values }\end{array}$ & Multiculture & Novel \\
\hline 1. & $\begin{array}{l}\text { Locality toward } \\
\text { nationality }\end{array}$ & Malay (Bangka)-China & Laskar Pelangi \\
\hline 2. & $\begin{array}{l}\text { Nasionalitas } \\
\text { menuju globalitas }\end{array}$ & $\begin{array}{l}\text { (a) Indonesia (Java-Bali-North Sumatra } \\
\text { (Batak)-Menado- the US } \\
\text { (b) Indonesia-Tibet-the US-Singapore } \\
\text { (c) Indonesia-Egypt-Turkey-the US } \\
\text { (d) Indonesia-France-Japan } \\
\text { (e) Indonesia-England-the US }\end{array}$ & $\begin{array}{l}\text { Larung } \\
\text { Jendela-jendela } \\
\text { Ayat-ayat Cinta } \\
\text { Jepun Negerinya Hiroko } \\
\text { Partikel }\end{array}$ \\
\hline
\end{tabular}

are found as suggested by Tilaar, namely (1) appreciation of cultural pluralism, (2) valuation toward the natures of man and FHR, (3) responsibility of world community, and (4) responsibility of planet earth that are integrated in the narrative elements.

The six novels depict the integrations of the interactions of Indonesian people in the contexts of interethnic and internation that are not apart from the existing cultural diversity (pluralism). The multicultural values that are an appreciation toward cultural pluralism are seen in the novels. These multicultural values move from the encounter among interethnic cultures, particularly Malay-China (Laskar Pelangi), Java-Bali-Batak-Menado (Larung), to the encounter among internation cultures particularly Indonesia-the US (Larung), Indonesia-the US-Singapore-Tibet (Jendela-jendela), Indonesia-Egypt-Turkeythe US (Ayat-ayat Cinta), IndonesiaJapan-France (Jepun Negerinya Hiroko). Intercultural encounters that are followed by appreciation toward cultural pluralism arise from the interactions of the characters in the novels in the national or global contexts. These interactions occur as a result of the characters taking education or working in other cities (territories) or countries (Larung, Partikel, Jendela-jendela, Ayat-ayat Cinta). In further cases, some of these characters have internation marriages and live in countries that are not their origins (Jendela-jendela, Jepun Negerinya Hiroko, Ayat-ayat Cinta).

The existing multicultural values are expressed through narrative elements, and integrated within the characterization of the characters, descriptions of the settings, and the problems that are issued. It is seen that the novels are intended to deliberately to raise the issues of multiculturalism. The novel Jepun Negerinya Hiroko by Nh. Dini tells about the marriage between an Indonesian girl, Dini, and a man from the French consulate (Yves). This novel can be taken as an autobiography since the story in it mostly has a similarity with the lifeline of Dini. Dini even did not change the name of the character in the novel with a fictitious name. It can be said that the novel is written to tell about her experiences in living along with her internation marriage within the multicultural world interactions, particularly when her husband and she stay in Japan.

Appreciation toward cultural pluralism is also seen in Jepun Negerinya Hiroko. In the Japanese setting, it is told how Dini, who comes from Java, is married to Yves Coffin, a French vice-consular in Japan, so that she has to move from Jakarta to Japan. They are married by willingly appreciating the differences in the cultures attached to them. They study and appreciate each other's cultures. In order to know more 
about Indonesia, Dini's husband takes along Javanese spices and recipes and books about Indonesian cultures in the moving trunks (Dini, 2015:2). On the other hand, Dini also learns much about French cultures such that, when she takes the interview in the French Embassy in a requirement to become wife of a French official, she is readily able to answer some questions about French artists.

And I can answer the Cultural Representative's questions about French writers or artists with full confidence. Names like Guy de Maupassant, Victor Hugo, Emile Zola. Balsac. Prevert, Utrillo, Monet, Manet, Voltaire, Rimbaud, George Sand, Moliere are not foreign to me .... (Dini, 2015:3).

Other than that, because they stay in Japan, they must also accept and appreciate Japanese cultures. Appreciation toward Japanese cultures is shown by Dini in the quaotation below.

Japan is an amazing country. The people, whom I used to know as soldiers with yellow skin, short, narrow-eyed, and rueful expressions, in their native land are to me friendly and polite. In the residences, markets, shopping centres, and even in the street, they are mostly caring and ready to help ... (Dini, 2015:11).

The thing that I find and that immediately touches my heart is the Kabuki. That show played by men really fascinates me from the first time I watch it. This cannot be equated with ludruk although the two shows have their own attractiveness.

Kabuki is an ancient folk show that has developed to a contemporary stage modified and packaged in a modern way but still maintain its classical or standard characteristics. I like it greatly. I can compare it with wayang orang in Semarang ... (Dini, 2015:13).

From the quotation above, it can be seen that by raising the life of Dini, who comes from Java, and her husband (Yves), who comes from France, Jepang, Jepun Negerinya Hiroko clearly uphold multicultural values that unite the cultures of Indonesia, France, and Japan.

In Jendela-jendela, it is told how June, an Indonesian, Javanese ethnic, is married to Jigme, a Tibetan. The two live and work in Singapore. June and Jigme met in the US when they were taking their university studies. Without neglecting the teachings and values of Indonesian and Javanese cultures, in order to be able to interact, moreover now that she is married to a foreign person, June must have appreciation toward US, Singaporean, and Tibetan cultures. The same case happens with Jigme who must have appreciation of the Javanese, Indonesian, American, and Singaporean cultures, in addition to his own. The following quotation shows this.

I am tired of living in a metropolitan city like Jakarta. I think New York, Los Angeles, Chicago and other famous cities are not far different from Jakarta. I think it is in the middle of Kansas, in the state where Dorothy from the movie Wizard of $\mathrm{Oz}$ lives or, more exactly, in the heartland of America that I want to live. My choice to study at Pittsburgh State University (PSU) was not wrong. The place where I study including Pittsburgh is like a fried egg, in which the university is the yellow and the city the white. This city, so it is told, was once popular in the 1920s for there was a place for mining coal. Many Europeans, particularly from the Balkan territory, came ... (Basuki, 2001:4). 
The comfort of living in Singapore, though not having a car, public transportation is guaranteed. Guaranteed in the sense of clean, fast, and regular. How is it not clean, in the SMRT (Singapure Mass Rapit Ytansit) the fast subway train and also in the public buses, there is prohibition to eat or drink during the journey ... Walls or fences or or buildings in Singapore are free from wild scribbles coolly called graffiti. No matter Singaporeans or foreign visitors, if they break the rule can be fined 500 to 1000 Singaporean dollars or punished by whipping. Because the law is practiced correctly, everything must be in order (Basuki, 2001:18-19).

The quotation shows the appreciation toward the values of the diverse cultures from various countries by June. June and her husband, Jigma, lives and works in Singapore, a multicultural state in Asia. June works for the International Voice, Indonesian section, a radio broadcasting company that broadcasts programmes in English, Malay, Chinese-Mandarin, Tamil, and Indonesian. June's multicultural spirit grows from her familial backgrounds. She comes from the Javanese ethnicity, of the higher middle level, living in Jakarta. Both her parents had education abroad, which makes it rational that June studied abroad.

My family lives in the vicinity of Cinere, South Jakarta, in a two-storey house of a medium size. My father is a chief drilling officer in a foreign oil company. My mother sometimes works as a public relation person. My father is a graduate of the University of Huston, Texas and my mother once joined a business program in New Zealand. So they are we are, me and Brother Bowo, we study abroad ... (Basuki, 2001: 29).
Through the character June, the novel Jendela-jendela depicts the appreciation of Pittsburg and Singapore which become part of June's life journey. What is interesting about the character June is that, even though she has lived and enjoyed foreign life and culture, and she has even preferred to marry a foreign person (Jigme from Tibet), she still retains her identities as a Javanese person not forgetting the teachings and values of the Javanese cultures that she once read in Ronggowarsito's work Serat Jayengbaya. She described and interpreted a number of verses from that book in an attempt to understand the political situation of Indonesia in 1998. In her mind, many people in Indonesia at that time are like the characters in Jayengbaya, fighting each other to become officials and leaders (Basuki, 2001: 94-97). Her identities as a Javanese person also surfaced when she got a swelling lump on her neck. She did not only have faith in the medical treatment in Singapore, she also resourced to Javanese alternative medication that linked this swelling with supernatural power. On her mother's suggestion, she went along with alternative medication in Jakarta and was cured.

In Laskar Pelangi, appreciation toward cultural pluralism is seen from the interethnic harmonious relation of the people living in Belitong, especially of the Malay and Chinese ethnics. The following quotation shows this.

The number of the Chinese people in our village is around a third of the total population. There are Kek, there are Hokian, there are Tongsan, and there are those who do not know their origins. It may be they earlier inhibited this island than anybody else ... This community is always typical: humble and hard-working. Though they are far apart from their cultural roots, they are lucky since they do not need to go far to Jinchanying if they only want 
to look at the Great Wall of China ... (Hirata, 2005: 35).

Harmonization of the Malay-Chinese is depicted in Laskar Pelangi in accordance with the social historical facts. In an article, "Melayu-Tionghoa Bersaudara Tanpa Sekat" (Wawa, 2011), it is stated that, in 2011, the population of the Chinese in Bangka Belitung was about $30 \%$ of the total 1,2 million people in that territory. They professed in various fields of works such as business persons, farmers, fishermen, tailors, vegetable vendors, fruit sellers, teachers, and office workers. Of the origin of the community of the Chinese in Bangka, according to a Bangka learned person Akhmad Elvian (via Wawa, 2011), it was in the 1757-1776 period on the wish of Sultan Ahmad Najamuddin Adikusuma, son of Sultan Mahmud Badaruddin II, who at that time ruled Sriwijaya Kingdom. Chinese people were brought to Bangka to increase the product and quality of tin since they were regarded as more skillful and mastering the technology of tin mining. Subsequently, more Chinese with more varied professions to build a wider range of relations between the Chinese with the local people. Akhmad Elvian (via Wawa, 2011) also states that the present Chinese people in Bangka are offspring of the natives and the Malays so that they have tighter brotherhood and harmony. The assimilation of the Chinese and the natives by marriages creates the saying fan ngin, to ngin jit tong meaning the indigenous, the Malay, and the Chinese are all the same and equal (Wawa, 2011).

To depict the harmonization of the Malay-Chinese, which is one of the forms of appreciation toward cultural pluralism, Laskar Pelagi tells about A Kiong, son of a Chinese family, who goes to an Islamic school (Gantong Muhammadiyah Elementary School). A Kiong's father, who is called A Liong and a Kong $\mathrm{Hu} \mathrm{Cu}$ believer, chooses to send his son to a Muhammadiyah elementary school, of a different religion from the one he embraces, not to Sekolah Nasional, a school for Chinese children (Hirata, 2005: 253). Youth love relation between the characters Ikal and A Ling who are of different ethnics and religions shows the existence of appreciation toward cultural pluralism in Bangka. From the story, it is clearly shown how differences in ethnics and religions do not raise problems in Belitung; they even do not upset the community's harmony.

In the novel novel Larung, appreciation toward cultural pluralism is shown by the friendships among the characters from various ethnicities. Shakuntala, Laila Gagarina, and Wisanggeni (Saman) come from Java, Yasmin Moningka from Menado, Cokorda Gita Magaresa (Cok) and Larung from Bali, and Sihar Simatupang from Batak. Appreciation of cultural diversity among individuals from various ethnicities becomes key to their friendship. In the friendship nobody attempts to expose the identities of their cultures. Such story of friendship is depicted in the novel Saman (1998), the first of the serial that is succeeded by Larung (2001).

Other than the friendship of the characters coming from various ethnicities, multicultural values in Larung is also seen in the multicultural interactions between Indonesia and America carried in by Shakuntala who studied choreography in the United States. The novel also describes how Shakuntala performed a dance show in Lincoln Center in New York before an American audience. In the show, Shakuntala danced the characters of Sita, Rama, and Rahwana of the Ramayana epic. Her Indonesian friends (Yasmin, Cok, and Laila) also came to the show.

"We're going to Tala's show in Lincoln Center. And I've got advocation appointments with Human Rights Watch and The World Forum...

What're you writing on?" 
I say, in nine days we're leaving for New York. Main aim: watch a collaboration dance show of Indonesian-American artists. Side aim: make love ... (Utami, 2001: 77-78).

Shakuntala danced Sita, Rama, and Rahwana. She shifted roles by moving around. She was breast naked, just wearing a cloth and shawl ... (Utami, 2001: 126)

The collaborative show of the Indonesian-American artists is a clear form of multi-culturalism. In the collaboration, the two cultures (Indonesian and American) have equal roles and positions. In addition to showing multiculturalism through art collaboration, Larung also reveals how the characters in the novel have appreciation of the cultural pluralism that becomes a characteristic the American people, more particularly New York, which is one of the world multicultural cities. In another part of the novel, Larung also tells that there is in New York an international organization, Human Rights Watch, with workers coming from various countries, like Saman from Indonesia (Utami, 105).

In Ayat-ayat Cinta, the mark of multicultural values is seen in the character Fahri, a Javanese, who goes to $\mathrm{Al}$ Azhar University, Egypt and gets along with people from various countries. Fahri marries Aisha, a Turkish girl living in Cairo and of parents of Palestinian, Turkish, and Jerman blood. Fahri and Aisha first meet in an intercity metro in Egypt. By raising the interethnic marriage, the novel is seen as upholding multicultural issues; seeing that Aisha's parents have also taken internation marriage (Palestinian, Turkish, and German).

Before she is married to Fahri, Aisha has even tried to learn and understand the ways of life of Indonesian people from Indonesian students who live in Cairo, and also of the characteristics of Javanese women. All these show her appreciation toward cultural pluralism.

"Alhamdulilah I've learned the peculiarities of Javanese women, I am amazed. They are faithful, and caring for their family. In Java, a wife is fully involved in the family matters. Wives find out how to keep the kitchen cooking. Javanese women can live a simple life. Like Fatimah Zahra, daughter of the Prophet lives a simple life, taking water and baking bread by herself ...

I've studied Indonesian students, especially Javanese who have families in Cairo. They live very simply. Managing money in the best way. Completing each other. I'm ready to live like they do ... (El Shirazy, 2006: 214).

In addition to this, while living in an apartment in Egypt, Fahri also makes friendship with Maria and her family who embrace Coptic Christianity. Maria and her family live on the flat above where Fahri and other Indonesian students stay. Although they are of different ethnics and religions, they get along well and respect each other (El Shirazy, 2006: 9).

Other than appreciation toward cultural pluralism, in Ayat-ayat Cinta also appear multicultural values that highly uphold humanistic values and FHR, shown by the incident on the metro to a town in Cairo. On this trip, Fahri witnessed a verbal harassment done by Ashraf, a Cairo youth, on three American tourists, one elderly lady and a boy and a girl. "Ya Amrikaniyyun, la'natullah 'alaikum." (Hey, Americans, God' wrath with you). (Shirazy, 2006:25). Ashraf's hatred of Americans is due to Egyptians' opinions that America is the cause of the damages in the Middle East, inciting hostilities between Islam and Coptic Christianity. The US once accused the Egyptian Government and Muslim people 
of treating Coptic Christians badly. This accusation had an inclination of to pull down the friendship joints between the Muslims and the Christians that have been rooted for centuries (Shirazy, 2006: 26). In Fahri's mind, what Ashraf did in the incident was indecent and far from the teaching of Al Qur'an. The commotion in the metro got worse when a veiled woman approached the American tourists and talked to them. She apologized for Ashraf's indecent behavior who had said rude words to them. This action had triggered the anger of an Egypt man wearing a box stripe shirt.

Yakharab baitik (May your house fall down). You've humiliated all the Egyptians who are on this metro. You're truly too much! It looks you're veiled, but you're a bitch that's what you are! You think that we're not polite, are we? We deliberately ignored those Americans to give them a small lesson. See, you didn't back up us. On the contrary, you let those demons have a seat. You look as though you were good, you wish to yourself you were a hero, asking for apology for us all. Who do you think you are, huh? (Shirazy, 2006:29-30).

Fahri, who appreciates diversity and highly upholds humanity, told Ashraf and his friend in stripe shirt and made them understand that their behavior toward the foreign tourists was indecent since it was not in accord with the characters of the Egyptians who were known as people who were hospitable, friendly, generous, and loving just like the characters of the Prophets Yusuf and Ya'qub (Shirazy, 2006:35).

"Nobody likes wicked things done by anybody. Including those by the US. But what you did like that was not right, far from the beautiful teachings brought by our Prophet."
"And so what should we do? Now that they are here. Now that there is a chance. By a small lesson, they will know that we do not like their evil behaviors. Later when they're back home in their country, they can tell their friends, the people there how we so dislike them."

"What you did, on the other hand, not adult just like children, strengthens the opinion of the American mass media that has so far believed that the Muslims are rude, do not have humanity. In fact, his honour the Prophet teaches us to be hospitable with our guests. Have you forgotten, he said those who have faith in Allah and the judgment day so respect your guests. These three people are guests in our good earth. They must be respected well ... (Shirazy, 2004:36).

They have the same rights as we Muslims do. Their blood and honour are the same as ours. They must be guarded and protected. They must not be hurt at all. And you must know, these three American tourists entered Egypt legally. They paid for the visa... (Shirazy, 2004:38).

From the quotations above, it is seen how Fahri tries to uphold toward humanism and FHR over diversities in ethnicity and religion in accordance with the teaching of the Prophet Muhammad. Valuation toward humanism and FHR contained in the novel Larung is seen from in Saman who works for the Human Rights Watch in New York (Utami, 2001:105). The Human Rights Watch is an international non-government organization (NGO), based in the US, that conducts research and protection in human right violations. The employees of Human Rights Watch cooperate with defenders of human rights in conducting research in about 90 countries around the world (www.hrw. org). 
Partikel does only raise multicultural values in relation to the appreciation of cultural pluralism and upholds humanism and FHR as reflected by the characters in the novel who come from various countries and ethnicities, but it also brings forward multicultural values in the forms of responsibilities for the world community and for planet earth. Appreciation toward cultural pluralism also appears in the novel Partikel by Dee (Dewi Lestari). This novel tells about persons who come from various ethnicities and countries and who meet and are gathered in the same work. Starting from the story of the character Zarah who wins a photography contest to join a tour to the Tanjung Puting National Park in Kalimantan, the novel describes the multicultural values and appreciation of the cultural pluralism of the people from various countries who are involved in the orangutan conservation program in the national park.

But in this last camp I felt a difference. The community here was so alive. Not only tourists who came presently and went again. Here there were volunteers, university students, and researchers from various parts of the world. I felt I was living in a tiny international village, internations. Interspecies.

While in the previous camp, who was waited for was Marlon, here the spotlight went to an elderly lady of 50, “Dr. D.”... (Dee, 2012: 191).

In Tanjung Puting, Zarah did not only meet Mrs. Inga, who taught her how to take case of orangutans, but he also met a group of wildlife from England, dari Inggris, Paul Daly, Zach, and Gary who were gathered in The A Team. The meeting subsequently brought Zarah to join the group that was stationed in London. Zarah was not only positioned in London, but she was also sent to a number of countries to document the behaviours of rare animals. Her work enabled her to meet people from different nations, ethnics, and cultures.

Pekerjaan Zarah mempertemukannya dengan orang-orang dari berbagai suku bangsa yang berbeda etnik dan budaya. Without having appreciation toward cultural pluralism, it would have been difficult for Zarah to carry out her life and profession in different countries such as England, Kenya, and Bolivia.

Appreciation toward humanism and FHR in Partikel can also be seen in the activities of Paul and his colleagues in The A Team in giving aids to a number of humanistic missions.

dalam membantu sejumlah misi kemanusiaan. The A Team, chaired by Paul, an English citizen, was name of a business enterprise in wildlife photography having an office in London. It is here that Zarah joined the group as a photographer and lived in London. Her occupation was not only taking photos of wild animals from various countries, but was also involved in various humanistic missions such as research in AIDS in Africa, disbursement of food substances to help with the food crises in Kenya, and saving and preservation of life environment.

"Wildlife photography is a very tough business," explained Paul.

"Very hard for a wildlife photographer to go up to this level and is paid expensively for his services. Can take years ....

For that, Paul makes use of his network he's established. During the last four years, Paul "infiltrated" his friends into various projects around the world among colleague wildlife photographers who were not as fortunate as Paul but who had great talents and potentials. When there was a medical journal research Afrika about AIDS, for example, in order to provide a guide for the research team, 
jadi tim pengawal para peneliti itu, Paul recruited one of his friends. The job was not only taking photographs, but also became a handy person who would be ready to be asked to do many things .... (Dee, 2012: 243).

Seven weeks had I been in London. My first assignment finally turned up. Kenya. I was going to join a team from FAO to disburse food aids and at the same time took data of the food crises that hit Kenya because of a long drought. My job period was not second rate. Three months. Paul was going to accompany me during the first week .... (Dee, 2012: 291-292).

From the quotation above, it is seen how Zarah and her friends conducted their activities in the AIDS research in Africa and the disbursement of food aids in Kenya together with other international humanistic organizations. Those activities are cultural and international humanistic activities that depict multicultural values and responsibilities for humanism and FHR. The problems of health and food consumption are the responsibility of all the people all over the world. Therefore, all people in the world must be responsible to handle it. It is seen from all the novels that valuation humanism and FHR crosses over the boarders of nations and countries. So, humanistic aids do not look at differences in nations, states, races, and religions. From a report by $F A O$ (Food Agriculture Organisation) year 2004, Kenya was one the East African countries that suffered from acute food crises because of long droughts. For that reason, FAO declared that Kenya needed continuous international aids (www.fao. org). Zarah was not only involved in the humanistic mission in Kenya and Africa, but she was also sent by the WHO, the world health organization, to document the Ebola virus epidemic (Dee, 2012: 6).
The multicultural values in the form of responsibility for planet earth can be seen in the activities of saving and preserving life environment, conservation of orangutans in Tanjung Puting, Kalimanantan, and introducing and documenting flora and fauna from around the world by way of wildlife photography. In Partikel, Zarah narrated as working as a photographer for The A Team Wildlife, being in charge of documenting various species of flora fauna from various parts of the world by her camera. Wildlife Photography documents the lives of wild animals in their original habitats. A wildlife photographer is an animal lover who loves life in the wilderness (http://www.rancahpost. co.id). The aim of the photography is to photograph of interesting animals' activities such as when they are eating, flying, fighting, etc. The photographer uses long telelenses to shoot objects from a distance (http://www.info-fotografi. $\mathrm{com} / \mathrm{blog}$ ).

The multicultural values in being responsible for planet earth are seen from the visions held by Zarah and her friends as wildlife photographers; that is, introducing the earth and all its contents to people at large.

“... If you don't take this picture, how would you expect one to have an eye contact with a crocodile? Very few will be capable of staying for months in the Arctic to tail polar bears. If nobody does it, how would people on the other half of the earth know the existence and beauty of polar bears? For me, wildlife photography is a bridge for a lot of people to know their own home. This earth. I see our profesion as an important bridge that connects Earth and human population. We're the ambasador of nature." (Dee, 2012: 253).

From the dialogue between Paul and Zarah above, it can be seen that a wildlife 
photographer's occupation is a noble one, being a bridge that connects man with the earth and all its beauties that, so far, they have not known. This is in accord with multicultural values in responsibilities for planet earth.

\section{From Multicultural Locality to Multi- cultural Nasionality, dan Globality}

The multicultural values that are uncovered in the six novels move from local cultural diversities to national and global cultural diversities. The dynamics of the movement from locality to nationality can be seen in Laskar Pelangi and Larung; the former describing the harmonization of Malay ethnics and cultures, especially Bangka and Chinese, the latter describing that of Java, Bali, Batak, and Menado. By presenting characters from various ethnics in Indonesia, the two novels clearly attempt to raise multicultural values as a diversity in unity. However, while Laskar Pelangi introduces characters whose activities are restricted to the scope of the island of Bangka (Indonesia), Larung extends its characters' activities to the transnational interactions, especially America. Shakuntala and Saman who study and work in New York, the United States, clearly represent Indonesian citizens in the global interactions.

Interethnic encounters among Indonesian-Tibetan-American-Singaporean cultures in Jendela-jendela, IndonesianEgyptian-Turkish-American cultures in Ayat-ayat Cinta, Indonesian-FrenchJapanese cultures in Jepun Negerinya Hiroko, and Indonesian-English-American cultures in Partikel show the dynamics of the cultural interactions moving from the nationality toward globality, that are internalized not only by Indonesian citizens but also by the world citizens. By involving characters who conduct internation marriages (IndonesianTibetan in Jendela-jendela, IndonesianTurkish-American in Ayat-ayat Cinta, and
Indonesian-French in Jepun Negerinya Hiroko), it is clear that the novels raise multicultural matters in the life of the Indonesians that will bring about broad impacts for the coming generations that will be the integration of two different nations and cultures.

Unlike the three novels above, that wrap multicultural values in internation marriages, Partikel raises multiculturalism in encounters and cooperations among individuals in various humanistic missions and preservation of the planet earth. There is Mrs. Inge, American, who devotes to the protection of orangutans in Tanjung Putting National Park; there are the wildlife photographers, including Zarah, who are not only in charge of documenting various flora and fauna around the world, but are also involved in the humanistic missions held by world organizations such as the FAO and WHO. These characters and the movements they are doing show the existence of multiculturalism that has crossed over the boarders of countries and nations to move forward globality.

From a number of Indonesian novels that raise multiculturalism as one of the themes, it can be said that the writers have a part in the development of the Indonesian society that is multicultural in the midst of the world nations. Novels that carry multicultural values can be included in the genre of multicultural literature (Imron, A.M., 2007: 97). Referring to Suparlan's opinion (2002:98), that society may be realized if the concepts of multiculturalism spread widely and its importance is felt by the Indonesian people, there is common understanding among the experts on the meaning of multiculturalism and the elements that support it, and there are attempts to make the idea come true. Dissemination of multicultural values by way of literary works is one of the attempts to realize an Indonesian society that is multicultural. 


\section{CONCLUSION}

Research findings show that (1) there are four multicultural values contained in the novels being studied, namely (a) appreciation toward cultural pluralism found in all the novels, (b) valuation toward humanism and FHR found in all the novels, (c) responsibility for the world community found in Partikel, and (d) responsibility for the planet earth underlying the theme of Partikel; (2) the multicultural values are expressed by way of the narrative elements as an integral part of the whole story; (3) the multicultural values move in the dynamics of locality toward nationality (Laskar Pelangi: Malay-Bangka-Chinese), nationality toward globality (Larung: Java-Bali- Batak-Menado-Amerika; Jendela-jendela; Indonesia-Tibet-AmericaSingapore; Ayat-ayat Cinta: IndonesiaEgypt-Turkey-America; Jepun Negerinya Hiroko: Indonesia-France-Japan; Partikel: Indonesia-England-America). From the research findings, it is sound that Indonesian novels of the 2000s attempt to present the Indonesian people in the contexts of the multicultural nations and world communities who have the appreciative spirits toward cultural pluralism, highly uphold humanism and FHR, and take the responsibilities for maintaining the peace and unity of the world and planet earth.

\section{REFERENCES}

Basuki, Fira.2001. Jendela-jendela. Jakarta: Gramedia.

Bhaba, H. 1994. Nation and Naration. USA \& Kanada: Routledge, Taylor \& Francis Group.

Dee (Dewi Lestari). 2015. Partikel. Yogyakarta: Bentang.

Dini, Nh. 2001. Jepun Negerinya Hiroko. Jakarta: Gramedia.
Denzin, Norman K., \& Lincoln, Yvonna S. 1994. Handbook of Qualitative Research. Thousand Oaks, London, New Dehli: Sage Publication International Educational and Professional Publishers.

El Shirazy, Habiburrahman. 2004. Ayatayat Cinta. Jakarta: Basmalah.

Hirata, Andrea. 2005. Laskar Pelangi. Yogyakarta: Bentang.

http://www.infofotografi.com/blog. diakses melalui google.com 25 Juli 2016.

http://www.rancahpost.co.id. diakses melalui google.com 25 Juli 2016.

http:// www.fao.org. diakses melalui google.com 25 Juli 2016.

http://www.hrw.org. Diakses melalui google.com 25 Juli 2016.

Imron A.M., Ali. 2007."Multikulturalisme dalam Novel Burung-burung Rantau Karya Y.B. mangunwijaya," Litera, Vol 2, No. 1, hlm. 97.

Parekh, Bhiku. 2001. Rethinking Multiculturalism: Cultural Diversity and Political Theory. United Kingdom: Macmillan Press.

Suparlan, Parsudi. 2002. “Menuju Masyarakat Indonesia yang Multikultural," Antopologi Indonesia, No. 69, hlm. 98-99.

Tilaar, H.A.R. 2009. “Pendidikan Multikultural" dalam Kekuasaan dan Pendidikan. Jakarta: Rineka Cipta.

Teeuw, A. 1988. Sastra dan Ilmu Sastra. Jakarta: Gramedia.

Utami, Ayu. 2001. Larung. Jakarta: Gramedia Pustaka Utama.

Wawa, Jannes Eudes. 2011. "MelayuTionghoa Bersaudara tanpa Sekat," dari http://edukasi.kompas.com/ $\mathrm{read} / 2011 / 11 / 25 / 03273151 /$ MelayuTionghoa.Bersaudara.Tanpa.Sekat. diunduh melalui google.com 10 Juli 2016.

(http://www.infofotografi.com/blog). 